\title{
Tissue-Engineered Heart Valves
}

\author{
E. FILOVÁ ${ }^{1,2}$, F. STRAKA ${ }^{1,2,3}$, T. MIŘEJOVSKÝ ${ }^{3}$, J. MAŠÍN ${ }^{3}$, L. BAČÁKOVÁ \\ ${ }^{1}$ Center for Cardiovascular Research, ${ }^{2}$ Institute of Physiology, Academy of Sciences of the Czech \\ Republic, Prague, Czech Republic, ${ }^{3}$ Institute of Clinical and Experimental Medicine, Prague, \\ Czech Republic
}

Received September 1, 2009

Accepted October 30, 2009

\section{Summary}

Currently-used mechanical and biological heart valve prostheses have several disadvantages. Mechanical prostheses, based on carbon, metallic and polymeric components, require permanent anticoagulation treatment, and their usage often leads to adverse reactions, e.g. thromboembolic complications and endocarditis. Xenogenous and allogenous biological prostheses are associated with immune reaction, thrombosis and degeneration, and thus they have a high rate of reoperation. Biological prostheses of autologous origin, such as pulmonary autografts, often burden the patient with a complicated surgery and the risk of reoperation. Therefore, efforts are being made to prepare bioartificial heart valves with an autologous biological component by methods of tissue engineering. They should be biocompatible, durable, endowed with appropriate mechanical properties and able to grow with a child. For this purpose, scaffolds composed of synthetic materials, such as poly(lactic acid), poly(caprolactone), poly(4-hydroxybutyrate), hydrogels or natural polymers, e.g. collagen, elastin, fibrin or hyaluronic acid, have been seeded with autologous differentiated, progenitor or stem cells. Promising results have been obtained with nanostructured scaffolds, and also with cultivation in special dynamic bioreactors prior to implantation of the bioartificial grafts into an animal organism.

\section{Key words}

Tissue engineering • Bioartificial heart valve • Nanofibrous scaffolds • Valve interstitial cells - Mesenchymal stem cells • Pulse flow bioreactor

\section{Corresponding author}

Lucie Bačáková, Dept. of Growth and Differentiation of Cell Populations, Institute of Physiology, Academy of Sciences of the
Czech Republic, Videnska 1083, 14220 Prague 4, Czech Republic. Phone: +420 29644 3743; Fax: +420 241062488. E-mail: lucy@biomed.cas.cz

\section{Introduction}

Cardiovascular diseases represent a major worldwide health care issue. According to the World Health Organization, cardiovascular diseases killed 17.5 million people in 2005, which represents $30 \%$ of mortalities. A considerable amount of these diseases is represented by heart valve failures. The number of patients requiring heart valve replacement is estimated to triple from approximately 290,000 in 2003 to over 850,000 by 2050 (Yacoub and Takkenberg 2005).

Heart valves are the aortic, pulmonary, mitral and tricuspid. In the surgical treatment of the aortic heart valve diseases, the currently preferred approach is heart valve replacement. In the case of mitral and tricuspid valves, conservative surgery of the patient's own native valve (i.e. valvuloplasty) is preferred in adulthood. Tricuspid and pulmonary valve operations are rare in adulthood, being performed in cases of significant regurgitation or endocarditis. On the other hand, clinical cases have been reported in which all four types of heart valves were replaced with prostheses, even simultaneously in one patient (Seeburger et al. 2009).

Currently used heart valve prostheses can be divided into two basic groups, namely mechanical and biological prostheses. Mechanical prostheses are mainly made of pyrolytic carbon combined with metallic and polymeric components. Although durable, these devices carry risks associated either with the valve itself, e.g. 
thrombus formation, thromboembolic complications, endocarditis that occurs predominantly on the surface of foreign materials, or risks connected with permanent and long-lasting anticoagulation therapy, e.g. hemorrhagebleeding complications occurring at $1 \%$ patients per year (Aschermann et al. 2004). On the other hand, long-term survival of patients (for more than 20 years) with mechanical heart valves without anticoagulation therapy and without complications has been also described (Yildiz et al. 2006).

Xenogenous and allogenous biological heart valve prostheses evoke an immune reaction of the patient's organism, thrombosis and undergo degeneration. The harvesting and implantation of autologous prostheses often requires complicated surgery with an increased risk of mortality. Therefore, an alternative way to improve the quality of heart valve prostheses is to construct bioartificial valves by tissue engineering methods.

The ideal valve prosthesis should be easy implantable, should develop a physiological hemodynamic performance without structural deterioration, should be non-thrombogenic, nonimunogenic and silent in its performance (Concha et al. 2004). Appropriate biomechanical properties of the tissue-engineered cardiac valve are extremely important, thus they are considered even to outweigh their biological properties. Otherwise, high pressure and stresses would result in valve failure, with potentially life-threatening consequences (Knight et al. 2008).

\section{Mechanical valve prostheses}

There are three major types of mechanical valves, namely caged-ball valves, tilting-disk valves and bileaflet valves, with many modifications on these designs.

The first artificial heart valve, implanted in 1952, was the caged ball, which utilized a metal cage to house a silicone elastomer ball (Hufnagel et al. 1958). During contraction of the heart, when the blood pressure in the heart chamber exceeded the value in the outside of the chamber, the ball was pushed against the cage and allowed the blood to flow. On completion of the heart's contraction, the pressure inside the chamber dropped, so the ball moved back against the base of the valve, forming a seal. A similar valve, commonly referred as the Starr-Edwards Silastic Ball Valve, was invented by Edwards and Starr in 1960 (Starr et al. 1985). It consisted of a silicone ball enclosed in a cage formed by metallic wires originating from the valve housing. Caged ball valves have a high tendency to form blood clots, so the patient must have a high degree of anti-coagulation. In addition, the movement of the ball damages the blood cells. Therefore, although caged-ball valves achieved the first long-term success in prosthetic heart valve technology, the Edwards Lifesciences Company discontinued their production in 2007.

A more advanced type of artificial heart valves is represented by tilting-disc valves. The first clinically available tilting-disk valve was the Björk-Shiley valve, introduced in 1969 (Björk 1977). Tilting-disk valves had a single circular occluder, controlled by a metal strut. These valves were made of a metal ring covered by a fabric of expanded polytetrafluoroethylene (ePTFE). In this fabric, the suture threads were stitched in order to hold the valve in place. By means of two metal supports, the metal ring holds a disc which opens and closes as the heart pumps blood through the valve. The disc is usually made of a very hard carbon material (pyrolytic carbon), in order to allow the valve to function for years without wearing out. In some models of mechanical valves, the disc is divided into two parts, which open and close like a door.

The newest design of mechanical valves, introduced in 1979 by St. Jude Medical Company, is the bileaflet valve. It consists of two semicircular leaflets that rotate about struts attached to the valve housing. The entire valves, i.e. the two leaflets, housing and struts, are made of pyrolytic carbon and avoid the stainless steel (i.e. cobalt-chromium-molybdenum-nickel-alloy) that was used in earlier valve types. Only titanium is still a component of the housing body in some designs (Zilla et al. 2008). Although bileaflet valves are vulnerable to backflow, and thus they cannot be considered as ideal, they provided much more natural blood flow than the caged-ball or tilting-disc implants. These valves have a greater effective opening area, are better tolerated by the body, are the least thrombogenic of the artificial valves, and thus they require only mild anticoagulation therapy (Emery et al. 1979, Emery and Nicoloff 1979; for review see http://en.wikipedia.org/wiki/Heart_valve_prosthesis\# Types_of_mechanical_heart_valves).

\section{Biological valve prostheses}

The adverse reactions that accompany implanted mechanical prostheses stimulated the development of biological prostheses. Stented glutaraldehyde-fixed 
valves, usually of animal origin, were developed in the 1960s; however, biological prostheses became more reliable and commercially available in the 1970s (Senthilnathan et al. 1999). At present, the following types of biological prostheses are available: porcine xenograft valves and bovine pericardial valves (i.e. implants derived from other species than human), allograft valves (also called homografts, and derived from human donors other than the patient) and autografts (i.e. derived from autologous patient's tissue) (Vesely 2005).

Both xenografts and allografts can evoke fibrotic tissue production, leading to valve dysfunction with incidence of 2-4\% patients/year, and the incidence of obstructive thrombosis is in the range of 0.2-1.8\% per year (Popelová et al. 2007). Re-surgery of these types of biological valve prostheses 15 years after their implantation into the body is indicated at $65 \%$ of patients under age of 60 . Both increasing age of the allograft donor and younger recipient age has been associated with allograft failure and a need for allograft valve reoperation due to accelerated valve degeneration (Yap and Yii 2004). Five-year survival of the allograft in right ventricular outflow tract reconstruction was $25 \%$ for recipients less than 1 year of age, $61 \%$ for those between 1 and 10 years, and $81 \%$ for those older than 10 years (Forbess et al. 2001). Age-dependent degeneration can be caused by many reasons, such as immunological response or progressive overgrowth of the implanted allograft by patient's fibrotic tissue. In addition, young patients exhibit increased hemodynamic demands on the allograft, as they are more active and have higher metabolic needs. In addition, valve procurement, duration of the allograft ischemia, time between valve harvest and valve implantation, and also the surgical method for implantation influence the long-term durability of the implant allograft (Yap and Yii 2004). Dehiscence of the prosthesis is also a serious complication that affects both bioprostheses and mechanical prostheses.

As for pericardial and other valves prepared from non-valvular tissues, Boenhoeffer et al. (2000) reported the first successful percutaneous valve replacement in a human patient, created from bovine jugular vein sutured into a platinum stent and placed in the pulmonary valve position. Two years later, another successful human percutaneous implantation of an aortic valve was performed. This valve was made of bovine pericardium sutured on a $23 \mathrm{~mm}$ balloon-expandable stainless steel stent, developed by Edwards Lifescience PVT (Irvine, CA) (Cribier et al. 2002).
Pulmonary autografts have been shown to be resistant to long-term degeneration and were confirmed to be able to grow in children (Concha et al. 2004). They can be used to replace the aortic root and all infected tissue in aortic valve endocarditis. Another indication for using an autograft is older age of the patients, where the graft can last longer than the patient (Senthilnathan et al. 1999). On the other hand, a pulmonary autograft implanted into the aortal position, i.e. the Ross operation, is a complex and demanding surgery with slightly increased mortality, where $20 \%$ of patients need reoperation 10 years after surgery (Popelová et al. 2007). This type of surgery involves replacing the aortic valve by the autologous pulmonary valve, and the pulmonary valve is then replaced by a pulmonary homograft.

A novel approach to the development of autologous heart valves is offered by methods of tissue engineering. It involves constructing valves using autologous cells and extracellular matrix (ECM) molecules, or a bioactive artificial material simulating the natural ECM. This procedure allows the histological structure of the natural valve to be fully respected. Deep knowledge of this structure, and also of the characteristic features of the cell types present in heart valves, is necessary for successful heart valve tissue engineering.

\section{Heart valve structure}

Microscopically, the heart valve (Fig. 1) is composed of three layers (Fig. 2), namely ventricularis, closest to the inflow surface and rich in radially aligned elastin fibers, fibrosa, closest to the outflow layer, containing predominantly circumferentially aligned, macroscopically crimped, densely packed collagen, and spongiosa, located in the central part and rich in glycosoaminoglycans (GAGs) and loosely packed collagen (Mendelson and Schoen 2006, Knight et al. 2008). Elastin restores the contracted configuration of the cusp during systole. Collagen fibers are inelastic and incapable of supporting large strains. Crimped collagen cords radiate primarily from the commissures. They confer strength and are responsible for withstanding diastolic stress; they maintain coaptation during diastole, when the cusp has the maximum area. During valve closure, the crimping expands in the radial direction, and increases in size with minimal stress. GAGs absorb shocks during the valve cycle and accommodate the shear of the cuspal layers. This structure enables the leaflets to be extremely soft and pliable when unloaded, and 

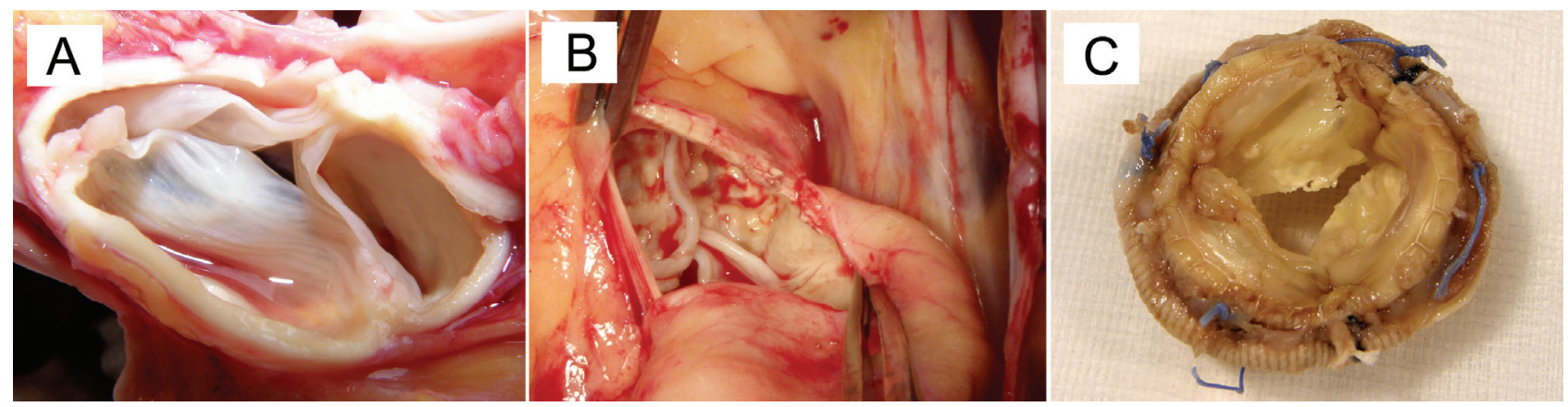

Fig. 1. A three-cusp aortic heart valve without pathological changes from an explanted heart with dilated cardiomyopathy (A), a perioperative picture of a three-cusp aortic valve with degenerative changes (B), and a biological prosthesis changed by endocarditis with a cusp perforation and vegetation (C).
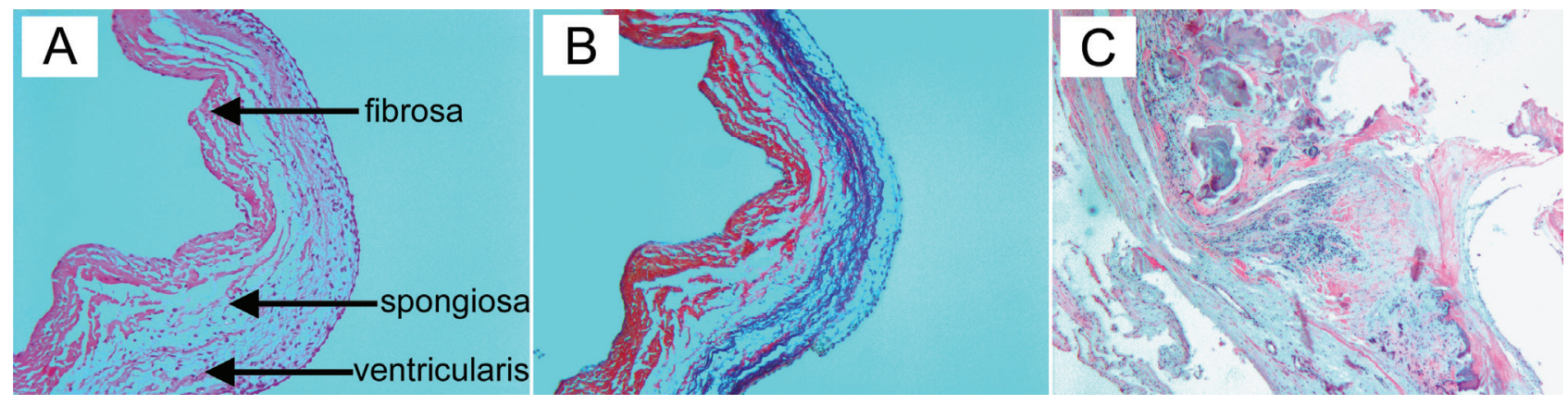

Fig. 2. Hematoxylin-eosin staining (A), and Sirius Red (nuclei and elastic fibres - black, collagen fibres - red) staining (B) of a threecusp aortic heart valve without degenerative changes, and hematoxylin-eosin staining of an aortic valve with degenerative changes, calcifications, and inflammatory infiltration (C). Microscope Leica 020-519.011DMLB 100S, blue filter, obj $\times 100$ (A, B), and $\times 50$ (C).

practically inextensible when back pressure is applied. In addition, they are anisotropic, having much higher tissue compliance in the radial direction than in the circumferential direction (Mendelson and Schoen 2006, Knight et al. 2008).

\section{Cell types present in heart valves}

Several cell types are present in heart valves, i.e. endothelial cells (EC), valve interstitial cells (VIC), fibroblasts, smooth muscle cells (SMC) and nerve cells.

EC create a non-thrombogenic surface layer and control immune and inflammatory reactions. Valve EC differ from vascular EC particularly in their reaction to mechanical stress, as they align perpendicularly to the blood flow, whereas EC from the aorta align in parallel to the flow (Butcher et al. 2004) (Fig. 2). In addition, EC are an important modulator of the VIC function (Schoen 2008).

VIC, the most numerous cell type in the valve, display morphological and functional characteristics of fibroblasts, smooth muscle cells and myofibroblasts. Five distinct phenotypes of VIC have been recognized, i.e. embryonic progenitor endothelial/mesenchymal VIC, quiescent VIC, activated VIC, adult progenitor VIC and osteoblastic VIC (Schoen 2008). VICs synthesize ECM proteins, matrix metalloproteinases (MMPs) and their inhibitors (TIMPs) that mediate matrix remodeling (Taylor et al. 2003). VIC have an activated myofibroblast-like phenotype during valve development and maturation, various diseases (e.g. myxomatous mitral valve), adaptation of an early pulmonary to aortic autograft (i.e. Ross operation) or during VIC remodeling (tissue-engineered valves in vitro and in vivo) (Figs 2 and 3) (Aikawa et al. 2006, Schurch et al. 1998). In their quiescent state, VIC have a fibroblast phenotype, characterized by the presence of vimentin and very low levels of $\alpha$-smooth muscle actin, MMP-13 and nonmuscle myosin heavy chain (SMemb). Taken together, VICs maintain the stability and integrity of the valves and are involved in synthesis and remodeling of the valve ECM (Fayet et al. 2007).

SMC in the valves have been observed in their less and more mature forms, i.e. in synthetic and contractile phenotypes, respectively. Terminally differentiated contractile SMC, characterized by the presence and mutual interaction of smooth muscle $\alpha$-actin and smoothelin, formed small bundles in the 

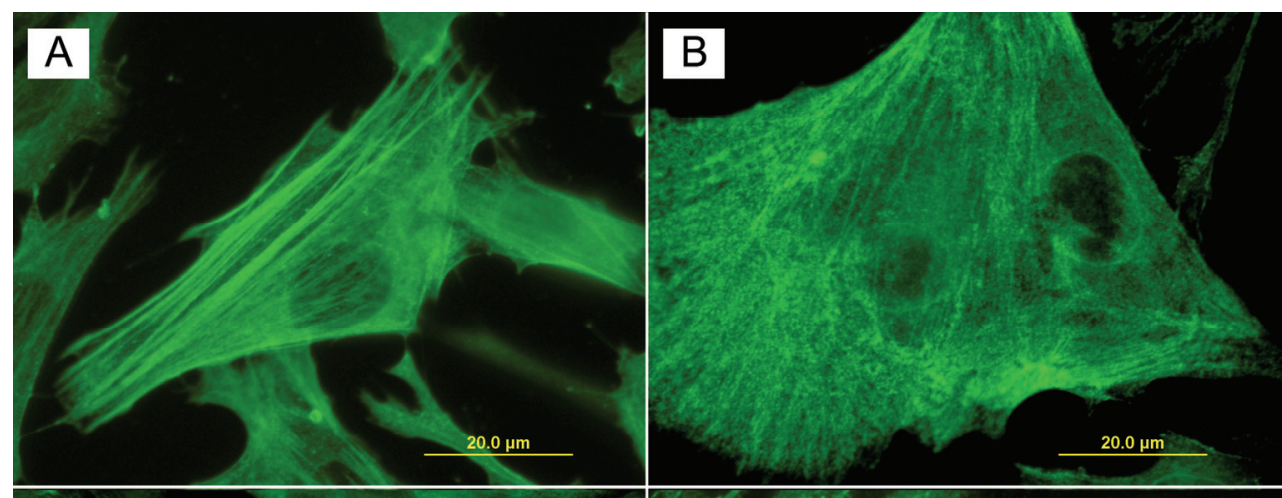

Fig. 3. Immunofluorescence staining of alpha-actin (A), myosin (B), vinculin (C), and talin (D) in valve interstitial cells from a pig aortic heart valve on day 3 after seeding. Olympus XI 51 microscope, DP 70 digital camera, obj. $\times 100$, oil immersion, scale $=$ $20 \mu \mathrm{m}$.
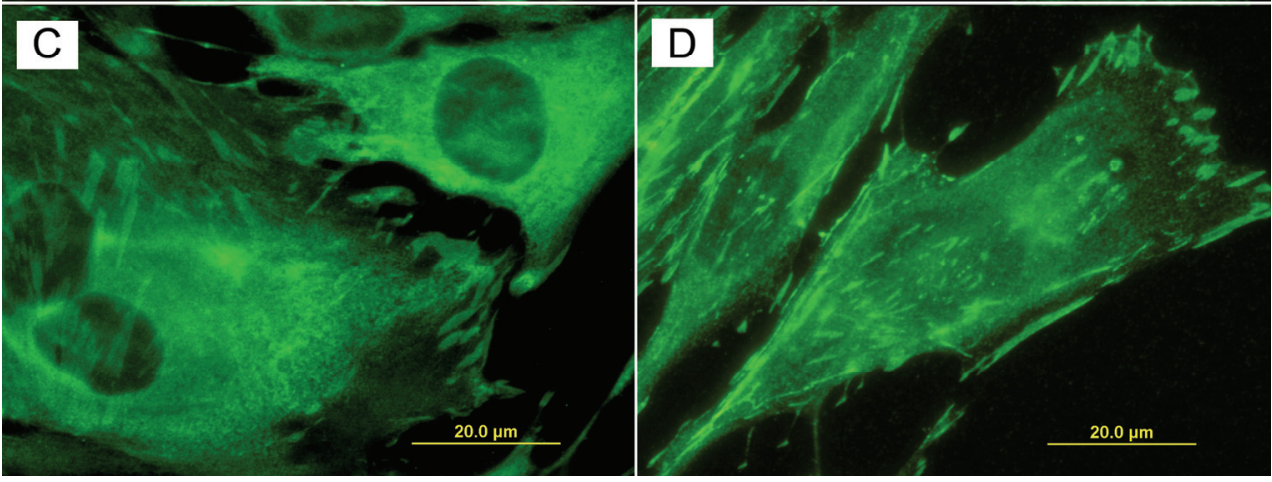

ventricularis, where they were oriented circumferentially. In addition, these cells were also distributed as individual cells throughout all valvular layers (Cimini et al. 2003).

The role of neurons in the heart valves is still not entirely clear. The valve leaflets contract in response to a variety of neurotransmitters, e.g. 5-hydroxytryptamin (Chester et al. 2000). Nerve branches are often associated with small vessels and are found predominantly in the basal third of the valve cusps (Weind et al. 2000).

\section{Tissue-engineered heart valves}

Currently, the following approaches are used for developing tissue-engineered valves (Vesely 2005):

Decellularized xenogenic tissues for cell seeding or direct implantation

It has been assumed that the antigenicity of xenogenic tissues, such as bovine or porcine pericardium, porcine small intestinal submucosa, and porcine or ovine heart valves is caused by cell debris (Vesely and Boughner 1989, White et al. 2005). In addition, porcine aortic valves need to be cross-linked by glutaraldehyde before implantation, which can cause cytotoxic and other adverse reactions. Glutaraldehyde-fixed pericardium was resistant to collagenase degradation and cell infiltration, but significantly prone to increased calcification (Tedder et al. 2009). Homografts (i.e. allografts), which do not require glutaraldehyde cross-linking, can last 15-20 years and have better mechanical properties than acellular glutaraldehyde-fixed xenografts. This favorable behavior likely results from the presence of interconnected sheets of collagen, layers and tubes of elastin, highly non-linear mechanics, anisotropy and viscoelasticity of native valve tissue (Vesely and Boughner 1989).

The decellularization technique has a different impact on tissue preservation and valve efficiency. Aggressive decellularization by enzymes (DNAase, RNAse), detergents, spit freezing and radiation, used in SynerGraft technology, resulted in catastrophic failure of decellularized xenogenic heart valves (Simon et al. 2003). On the other hand, deoxycholic acid completely decellularized heart valves, while structural proteins were retained and appeared to be intact (Booth et al. 2002). Decellularization of carotid arteries by distilled water, $0.025 \%$ trypsin, $1 \%$ Triton X-100 and ammonium hydroxide caused various structural changes of their ECM, such as less compact and more extended adventitial collagen, and increased spacing between fibrils. These alterations led to changes in mechanical properties, which involved a higher tensile modulus, lower extensibility, and decreased residual stress of the decellularized arteries, suggesting significant fiber network disruption (Williams et al. 2009).

Implantation of decellularized allograft and xenograft valves induces tissue regeneration in vivo with efficient repopulation of the matrix by interstitial cells, but graft endothelialization is not sufficient. Complete re- 
population of detergent-decellularized ovine pulmonary valves with endothelial cells was achieved in vitro in a dynamic bioreactor (Lichtenberg et al. 2006). In the bioreactor, EC were adapted to a relatively high flow of the medium by a progressive increase of flow rate from $0.1 \mathrm{l} / \mathrm{min}$ to $2.0 \mathrm{l} / \mathrm{min}$. If differentiated EC for seeding on the valve are less available, mesenchymal stem cells (MSC) can relatively easily be isolated from the bone marrow (e.g. bioptically from the iliac crest) and phenotypically converted into EC in vitro (Gojo et al. 2003, Marion and Mao 2006). MSC also provide a source for fibroblasts/myofibroblasts and smooth muscle cells. When MSC were seeded onto a decellularized porcine pulmonary valve pre-coated with fetal bovine serum and fibronectin, they colonized the scaffold, and endothelium lining, and the presence of fibroblasts and myofibroblasts was proved in the valve graft (Iop et al. 2009).

Another approach in engineering heart valves is the use of modified decellularized bovine pericardium (ABP) as a scaffold for cell colonization. ABP has advantages of good mechanical properties, being composed of native ECMs including collagen, elastin and various GAGs (Lai et al. 2006). The properties of this material were further improved by conjugation with RGD-containing polypeptides, which act as ligands for cell adhesion receptors. As a result, 10 days after seeding, human MSC attached much better, proliferated faster and ingrew deeper into the modified ABP scaffolds (Dong et al. 2009).

Constructs containing polymerized extracellular matrix and entrapped cells

Similarly as in the approach reported above, this technology also utilizes purely biological materials for valve tissue engineering. However, the cell carriers are made of more defined materials, represented by isolated ECM molecules, such as collagen, elastin, hyaluronic acid, fibronectin and fibrin.

Type I collagen is an important component of the vessel wall, and a major matrix protein of the bone and other connective tissues. Collagen as a biomaterial has a number of useful properties. It is biodegradable, biocompatible, non-antigenic, haemostatic, easily modifiable, acts synergetically with other bioactive components, is biologically plastic due to its high tensile strength and minimal expressibility, and is compatible with synthetic polymers (Lee et al. 2001). Excellent cell adhesion on collagen is mediated by cell membrane integrins, such as $\alpha_{1} \beta_{1}$ and $\alpha_{2} \beta_{1}$ (Tulla et al. 2001). Pure collagen, due to its fast degradation, often needs crosslinking or needs to be used in a blend with other polymers. Heart valve-shaped collagen scaffolds, prepared from decellularized porcine pericardium treated with penta-galloyl glucose, allowed time-dependent cell infiltration and collagen synthesis in vivo, while no calcium deposits were found (Tedder et al. 2008). However, fully cross-linked collagen reduces the cell infiltration and remodeling capacity, and thus might prevent tissue regeneration. On the other hand, non-crosslinked scaffolds may degrade too quickly and their functionality is threatened. A tubular vascular hybrid collagenous scaffold colonized with canine jugular smooth muscle cells resisted rupture pressure up to $110 \mathrm{~mm} \mathrm{Hg}$ (Baguneid et al. 2006). Collagen scaffolds composed of $1-5 \%$ collagen prepared by rapid prototyping allowed adhesion, proliferation of VIC in vitro (Taylor et al. 2006). This technique is advantageously used to prepare scaffolds of predetermined size and three-dimensional shape.

Elastin has been proposed for engineering of vascular grafts, heart valves, skin substitutes, or elastic cartilage (Daamen et al. 2007). In heart valves, there are several elastin architectures, i.e. sheet-like orientation in the ventricularis, sponge-like orientation in spongiosa and tubular to circumferential in the fibrosa (Scott and Vesely 1996, Daamen et al. 2007). Elastin peptides have been shown to reduce proliferation and migration of vascular smooth muscle cells in vitro and in vivo (Ito et al. 1997, Karnik et al. 2003). One of the problems connected with elastin as a biomaterial is its tendency to calcification, which occurs in cardiovascular prosthetic implants, e.g. bioprosthetic heart valves and aortic homografts. Elastin and also collagen may serve as nucleation sites for mineralization, independent of cellular components of the prostheses. Calcification can be reduced by treatment with aluminium chloride, ethanol/EDTA, the presence of glycosaminoglycans, or basic fibroblast growth factor (for review see Daamen et al. 2007). Elastin can be used in various forms, including an insoluble form present in autografts, allografts, xenografts, or in a soluble form. Scaffolds prepared from insoluble collagen and solubilized elastin induced angiogenesis, and increased elastic fiber synthesis without inducing calcification (Daamen et al. 2007). In other experiments, elastic lamina and collagen matrix scaffolds, prepared from rat aorta, were implanted into the host rat aorta. Reduced unwanted reactions, namely leukocyte adhesion, bromodeoxyuridine (BrdU) incorporation (i.e. a marker 
of DNA synthesis) and neointimal formation, were found on matrices composed of elastic lamina compared to collagen matrix (Liu et al. 2004).

Hyaluronic acid (HA) is a major component of cardiac jelly during heart morphogenesis (Masters et al. 2005). Hyaluronic acid and chondroitin sulphate compose about $90 \%$ of the total GAGs in human heart valves (Ramamurthi and Vesely 2005). It is non-immunogenic, non-thrombogenic, viscoelastic, and can be cross-linked to form a hydrogel (Masters et al. 2005). During wound healing, hyaluronic acid supports cell invasion into the provisional matrix (Clark 2001). Photopolymerization of HA did not reduce the viability of previously entrapped VIC (Masters et al. 2005). Degradation products of methacrylated $\mathrm{HA}$ have been observed to induce proliferation of EC, VIC, and also angiogenesis and ECM production, which can in turn improve the mechanical and biological properties of the gel. In addition, low molecular weight HA stimulated elastin production (Masters et al. 2005). Similarly, a composite material made from hyaluronan and elastin supported synthesis of elastin by neonatal smooth muscle cells compared to standard tissue culture polystyrene. On the composite gels, the cells proliferated and produced a higher ratio of insoluble elastin (Ramamurthi and Vesely 2005). Interaction between VICs and valvular endothelial cells, and their relationship to the formation of intercellular matrix have also been studied. Increased interstitial cell matrix synthesis and more confluent endothelial cell monolayers were observed after supplementation of collagen hydrogel with chondroitin sulfate (Flanagan et al. 2006). It seems that the interaction of VICs and valvular endothelial cells is essential for valve remodeling (Ruel and Lachance 2009).

Human fibronectin is a dimer composed of two nonidentical polypeptide chains which are disulfidebonded at their carboxyl termini (Faralli et al. 2009). The fibronectin structure, based on homologous repeating units termed I, II and III, gives a strong elasticity to the fibronectin fibrils. Fibronectin can stretch about four times its original length. During its stretching, novel cryptic sites are exposed, e.g. those located in the III1 repeat, which further promotes the fibronectin fibril assembly and stimulates cell growth and contractility (Hocking and Kowalski 2002). Fibronectin supports and guides cell adhesion, migration and alignment via integrin adhesion receptors on cells, namely integrins $\alpha_{3} \beta_{1}, \alpha_{\mathrm{v}} \beta_{1}, \alpha_{\mathrm{v}} \beta_{3}, \alpha_{\mathrm{v}} \beta_{5}, \alpha_{\mathrm{v}} \beta_{6}, \alpha_{4} \beta_{1}, \alpha_{4} \beta_{7}$ (Zhou et al. 1999). The cell adhesion mediated by $\alpha_{5} \beta_{1}$ integrins is optimal on the native fibronectin or its pre-stretched states, where the distance between the RGD-loop on the $\mathrm{FN}-\mathrm{III}_{10}$ module and a fibronectin synergy site, which is located on the $\mathrm{Fn}^{-} \mathrm{III}_{9}$ module, is $32 \AA$. Stretching increased the RGD-synergy site distance to $55 \AA$, which impaired cell spreading (Krammer et al. 2002). Integrin $\alpha_{\mathrm{v}} \beta_{3}$ does not recognize the synergy site and thus it is less sensitive; this means that $\alpha_{\mathrm{v}} \beta_{3}$-mediated cell adhesion is affected only if relatively high stretches are applied. Fibronectin was also observed to promote collagen contraction by fibroblasts. It was accompanied by a pronounced abundance of both phosphorylated and total paxillin, i.e. an integrinassociated protein present in focal adhesions. Other ECM proteins or glycosaminoglycans did not increase the collagen contraction (Liu et al 2006). Fibronectin serves as a depot for soluble factors, and binds other components of ECM, e.g. thrombospondin-1, which modulate cell cellular responses to ECM (Midwood et al. 2004). Other molecules mediating biological activities of fibronectin are syndecans and heparin sulphate proteoglycans, which interact with the heparin-binding domain of fibronectin via the heparin sulphate chain (Faralli et al 2009). Fibronectin can be used as an effective coating of artificial materials in order to support the adhesion and spreading of cells (Wittmer et al 2007). Fibronectin coating of polytetrafluoroethylene (PTFE) prostheses enhanced their endothelialization regardless of whether they were pre-seeded with EC in vitro prior to their implantation into dogs (Seeger and Klingman 1988). Co-adsorbed albumin improved poor cell spreading on fibronectin pre-adsorbed on hydrophobic surfaces (Horbett 1993). A possible explanation is that the coadsorption of albumin and fibronectin modified the geometrical conformation of fibronectin to be accessible for the cell adhesion receptors. This phenomenon, referred to as "albumin rescuing", caused a higher availability of fibronectin-cell binding domains on the surfaces of artificial materials, such as tissue culture polystyrene, microbiological polystyrene, and Teflon $\mathrm{AF}^{\circledR}$, if low concentrations of albumin were used (Koenig et al. 2003).

Fibrin is a provisional matrix protein participating in wound healing. Thus, it represents a biocompatible and biodegradable material interacting with tissue without inducing inflammation, foreign body reaction, tissue necrosis or extensive fibrosis (Bense and Woodhouse 1999; Jackson 2001). Fibrin can be advantageously used as an autologous material derived from the patient's blood. Encapsulation of the cells inside 
the fibrin gel has been applied for molding a valve conduit containing myofibroblast cells (Ye et al. 2000, Jockenhoevel et al. 2001, Mol et al. 2005, Grassl et al. 2002). In vitro experiments confirmed that fibrin promotes matrix synthesis through the release of plateletderived growth factor (PDGF) and transforming growth factor beta (TGF- $\beta$ ) (Jockenhoevel et al. 2001). As demonstrated by our earlier experiments, fibrin layers of various thicknesses can be prepared, ranging from ultrathin two-dimensional layers to a bulk threedimensional fibrin (Filová et al. 2009a, Riedel et al. 2009). These layers promoted the adhesion, spreading and phenotypic maturation of endothelial cells, thus they could be used for endothelialization of vascular and valve replacements. Disadvantages of fibrin include its poor mechanical properties, relatively quick degradation, and shrinkage due to structural changes and contraction of the newly synthesized collagen bundles (Jockenhoevel et al. 2001). In addition, increased intimal thickening has been reported in ePTFE grafts coated with fibrin and implanted into pigs (Walpoth et al. 2007). Mechanical properties of fibrin gels can be tailored by introducing it into composite materials. Three-dimensional matrices prepared from type I collagen, fibrin or a mixture of collagen and fibrin in a 1:1 ratio with embedded rat aortic smooth muscle cells exhibited a different stress-strain profile (Cummings et al. 2004). Pure collagen had the highest linear modulus and pure fibrin the lowest, while collagen-fibrin mixtures underwent the highest compaction. The gel compaction was further amplified, if cyclic mechanical strain was applied to the construct. At the same time, the proliferation activity of smooth muscle cells (which is generally considered as undesirable in vascular constructs) was reduced (Cummings et al. 2004). Dynamic conditioning of molded fibrin-based heart valve seeded with a mixture of smooth muscle cells and fibroblasts from ovine carotid artery in a bioreactor increased the cell attachment, expression of $\alpha$-smooth muscle actin (i.e. a marker of phenotypic maturation towards the contractile phenotype), enhanced deposition of types I and III collagens, fibronectin, laminin and chondroitin sulphate (Flanagan et al. 2007). ECM deposition can further improve the remodeling, mechanical properties and function of a graft. Fibrin is degraded by proteolytic action of plasmin and MMPs, and is gradually replaced by collagen and other ECM components produced by cells (Bense and Woodhouse 1999, Clark 2001). Fibrin degradation and remodeling can be slowed down by adding aprotinin, an inhibitor of plasmin, or $\varepsilon$-aminocaproic acid, an inhibitor of fibrinolysis, into the cultivation medium (Grassl et al. 2003), or by chemical or mechanical fixation of the gel (Jockenhoevel et al. 2001).

\section{Degradable synthetic scaffolds pre-seeded with cells}

Biological molecules used in the previous approach are often of xenogeneic origin (except fibrin, which can be derived in considerable quantities from the patient's own blood), and this can cause adverse reactions in the patient's organism. Therefore, in recent tissue engineering, great attention is being paid to synthetic cell carriers. Synthetic scaffolds used in heart valve tissue engineering have mostly been made of bioresorbable polymers, such as poly(glycolic acid) (PGA), poly(lactic acid) (PLA), poly(caprolactone) (PCL), polyhydroxyalkanoates, and copolymers or blends of these polymers, e.g. a blend of PGA or PLA with poly(4hydroxybutyrate) (P4HB) (Hoerstrup et al. 2002, Sodian et al. 2000). For example, very good results were obtained with PGA/PLLA nonwoven meshes seeded with mesenchymal stem cells (MSC). After 4-week cultivation in roller bottles, the cell-material constructs were implanted into sheep for 24 weeks. Although 2 sheep died, in the other animals MSC differentiated into cells that were positively stained for $\alpha$-smooth muscle actin, von Willebrand factor (i.e. a marker of endothelial cells) and vimentin (a marker of fibroblasts), and created a histological structure similar to a native valve (Sutherland et al. 2005).

In comparison with nature-derived materials, synthetic polymers are of more defined and controllable properties, and can be more easily reproduced. However, incompletely degraded polymers can evoke inflammation; the space formerly occupied by polymer and its interstices are replaced by fibrotic tissue, and the perfusion of deep parts of the scaffold is limited (Mendelson and Schoen 2006). Other promising polymers for the construction of bioartificial valves are soft and elastic hydrogels. Their mechanical properties correspond better to the properties of soft tissues than those of hard hydrophobic polymers such as PGA, PLA or PCL. Macroporous hydrogels prepared from recently synthesized degradable polymethacrylates induced only a minimal sterile inflammatory reaction in the surrounding tissue, probably only due to the surgery, and no foreign body reaction when implanted in the spinal cords of rats (Přádný et al. 2006).

Advanced technologies, e.g. rapid prototyping 
and nanospider technology, have been used recently for creating the nanoarchitecture of bioartificial constructs (Shih et al. 2006). The reason for this approach is that the natural tissues are built on hierarchically-organized macro-, micro- and nanoscale levels. Nanofibers seem to provide cells with a similar environment to the native ECM. A variety of polymers, such as poly(lactic-coglycolic acid) (PLGA), poly-L-lactide (PLLA), PCL, poly(ethylene oxide terephthalate)-poly(butylene terephthalate) (PEOT-PBT), collagen or chitosan, have been successfully electrospun. The diameter of the electrospun nanofibers ranged from ten to one thousand nanometers, and created a two- or three-dimensional structure with high surface-to-area ratios (Shih et al. 2006). Nanofibers made of type I collagen had multiple effects on MSC behavior, e.g. they increased the cell viability, induced a more polygonal and flattened cell morphology with numerous filipodia-like protrusions, and enhanced cell migration. Another positive feature was that the MSC displayed a lower activity of alkaline phosphatase, i.e. an enzyme involved in calcification, compared to the cells on standard tissue culture polystyrene (Shih et al. 2006). A technique enabling onsite layer-by-layer 3D tissue generation has already been developed, with the possibility to entrap different cell types simultaneously in one procedure (Yang et al. 2009). Fibroblasts seeded into a ten-layer collagen/PCL cellfiber construct were found to be evenly distributed throughout the scaffolds, they proliferated, and deposited ECM during 14 days of culture (Yang et al. 2009).

In our experiments focused on the use of nanotechnology in tissue engineering of bioartificial valves, nanofibrous scaffolds, made of PCL, PLA and gelatine by electrospinning in a nanospider machine, provided good supports for the adhesion, growth and phenotypic maturation of VIC derived from a pig aortic valve. These cells formed well-developed vinculincontaining focal adhesion plaques and a rich $\alpha$-actin cytoskeleton. These effects were more apparent in scaffolds with nanofibers aligned in parallel than on randomly-oriented nanofibers (Filová et al. 2009b).

\section{Response of valve cells to dynamic loading in vivo}

The aortic heart valve has a specific shape and undergoes a specific load during the cardiac cycle. Systole and diastole lead to different changes in shear stress and pressure load that bend the valve and subject the valve to tensile and compressive forces. Different loads act upon the ventricularis and fibrosa, i.e. the inflow and outflow side of the leaflet. This is caused by pulsatile blood flow and by the mechanics of valve opening and closure. The blood flow on the inflow (i.e. ventricularis) side is strongly unidirectional and pulsatile, whereas the flow on the arterial (i.e. fibrosa) side is much slower and more oscillatory (Kilner et al. 2000). The pressure gradients across the normal aortic valve in the systole, when the valve is open, are practically zero. In the diastole under physiological conditions, when the valve is closed, there is a pressure gradient between the left ventricle and the ascending aorta of about $80 \mathrm{mmHg}$. The shear stresses acting on the aortic valve leaflet surfaces range from 30-1500 dynes $/ \mathrm{cm}^{2}$ (Weston et al. 1999). Both valvular endothelial cells (VEC) and valvular interstitial cells (VIC) are sensitive to mechanical forces (Butcher et al. 2008). VIC isolated from the pulmonary valve were less stiff than those from the aortic valve, and these differences correlated with $\alpha$-smooth muscle cell actin content and the amount of collagen biosynthesis (Merryman et al. 2006). VICs are capable of remodeling the ECM, which is dependent on the mechanical loading. After the Ross operation, i.e. placing the pulmonary valve in aortic position, the change towards a higher pressure resulted in increased synthesis of collagen and glycosaminoglycans by pulmonary VIC. VEC in vivo align circumferentially on the leaflet surface, which is perpendicular to the direction of fluid flow, in contrast to arterial endothelial cells, which align in parallel (Deck 1986). It was further demonstrated that this alignment difference was regulated by changes in integrin clustering (followed by immunofluorescence of $\beta_{1}$ integrins), focal adhesion plaque formation (followed by immunofluorescence of vinculin), integrin-mediated signaling (through focal adhesion kinase) and cytoskeletal (i.e. f-actin) arrangement (Butcher et al. 2004). Moreover, DNA microarrays have shown statistically significant differences (approximately $10 \%$ ) in the genetic profile of porcine vascular (aortic) endothelial cells and valvular endothelial cells (Butcher et al. 2005). Steady shear stress was protective against oxidation damage, inflammatory reaction and chondro/osteogenic differentiation in both endothelial cell types (Butcher et al. 2005). Simmons et al. (2005) for the first time identified distinct endothelial phenotypes on opposite sides of the aortic valve. Over 584 transcripts were found to be differentially expressed in situ by the endothelium on the fibrosa versus ventricularis side of the 
valve. The fibrosa side of the valve is more sensitive to lesion formation; however, this vulnerability is balanced by an enhanced antioxidative gene expression profile, which means that the fibrosa of the normal valve may be protective against inflammation and lesion initiation. Side-specific differences in valvular endothelial gene expression may be due to the differences in hemodynamic profile on each side of the valve (Butcher et al. 2008). The valvular endothelium is probably derived from specific regions of endocardial endothelium during embryonic development (Eisenberg and Markwald 1995).

\section{Dynamic cultivation systems for valve tissue engineering}

For successful tissue engineering, including heart valve tissue engineering, it is necessary to simulate the physiological mechanical loading of the tissues in vivo by dynamic cultivation in vitro. Currently, two types of dynamic systems are used for in vitro tests: (1) simple systems, intended for unidirectional stretching or bending of samples that are not preformed in the shape of the valve and (2) sophisticated systems, with more physiological dynamic loading of the valve-shaped samples or bioengineered valves together with the entire aortic root. These systems use either steady or pulsatile flow produced by rotary or membrane pumps. The aim of the dynamic culture is to produce a physiological flow curve through the valve, to apply pressure and shear stress, and to bend the valves. An advanced bioreactor, i.e. the flow loop bioreactor, ensures a complex hemodynamic environment (Butcher et al. 2008). Proper mechanical stimulation represents the primary strategy for producing a functional tissue in vitro (Syedain et al. 2008). Especially for the construction of bioartificial heart valves, mechanical loading of the tissue is absolutely necessary. This loading stimulates growth and maturation of VIC and the formation of ECM by these cells. For differentiated VIC, this behavior is usual, but for MSC cels, mechanical conditioning is required for their differentiation towards VIC phenotype. In tissue engineering of the valves, pulsatile flow of the culture medium through the valve, or pulsatile back-pressure on the valve has been applied (Mol et al. 2005). Mechanical stimulation had fundamental effects on the differentiation of sheep bone marrow-derived stem cells on PGA/PLLA scaffolds. Increased tissue formation and expression of markers of endothelial cell phenotype has been observed only in the group with both cyclic and laminar flow (Engelmayr et al. 2006). It is known that cells adapt their behavior to constant environmental stimuli; that is why the cells initially respond but then return to baseline level after sustained stimulation ( $\mathrm{Li}$ et al. 2005, Syedain et al. 2008). A fibrin-based construct with porcine VIC exposed to constant $15 \%$ cyclic distension increased collagen content, ultimate tensile strength and tensile modulus after 3 weeks. Constructs subjected to cyclic distension with strain, which was incremented from $5 \%$ to $15 \%$ over the 3 weeks of cyclic distension, improved their mechanical properties (ultimate tensile strength, tensile modulus) as well as their collagen production compared to the constructs exposed to a constant strain amplitude (Syedain et al. 2008). Similarly, VIC and MSC that were stretched on collagen-coated flexible substrates increased their collagen synthesis at $14 \%$ stretch $(\mathrm{Ku}$ et al. 2006). In vivo, VIC are exposed to large strain values during each cardiac valve cycle, mounting by $24 \%$ in the radial direction and by $11 \%$ in the circumferential direction (Lo and Vesely 1995). In another study, PGA/PLLA 50:50 nonwoven fibrous scaffoldspolyacrylamide gel composites were seeded with smooth muscle cells and exposed to unidirectional cyclic threepoint flexure at physiological frequency and amplitude in a bioreactor for three weeks. This stimulation resulted in increased concentration and improved structuralmechanical properties of the collagen in the scaffolds (Engelmayr and Sacks 2008).

Cultivation of cells in a dynamic bioreactor enabling pulsatile flow of the culture medium had beneficial effects also on vascular cells in our experiments. Rat aortic smooth muscle cells and bovine pulmonary artery endothelial cells of the line CPAE, cocultured on Aramid (i.e. aromatic polyamide) nanofiber meshes in a dynamic bioreactor, formed a continuous bilayer. Both cell types in the bilayer were well-stained for their differentiation markers, i.e. $\alpha$-actin for smooth muscle cells and von Willebrand factor for endothelial cells. On the contrary, in the static culture system, only small islets of both cell types were observed, and the staining intensity for both differentiation markers was much weaker (Fig. 4) (Straka et al. 2009).

Dynamic cultivation is also a part of a novel approach to valve tissue engineering, known as "in-body tissue architecture technology". In experiments conducted by Nakayama et al. (2009), this technique started with the insertion of a silicone tube into the dorsal subcutaneous space of a rabbit. After encapsulation with connective 


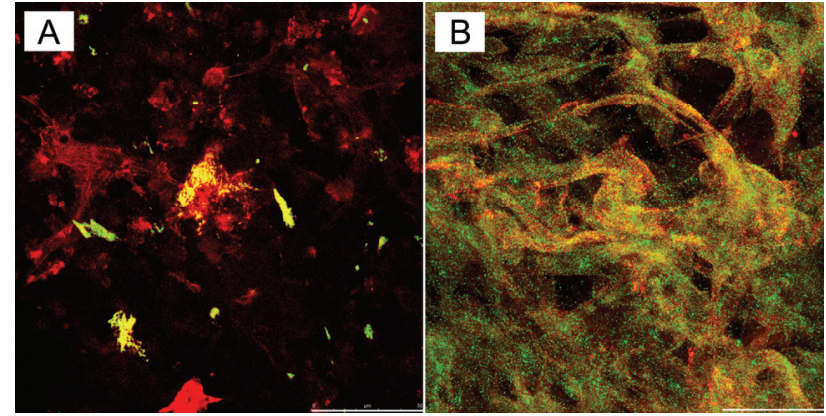

Fig. 4. Immunofluorescence staining of a-actin in smooth muscle cells (AlexaFluor 488, green) and von Willebrand factor (AlexaFluor 633, red) in endothelial cells under static (A) and dynamic culture conditions (B) on Aramid nanofibre mesh after 17 days in culture. Leica SPE confocal microscope, obj. $\times 40$, zoom $\times 1.5$, oil immersion, scale $=50 \mu \mathrm{m}$.

tissue, the rod was harvested and a polyurethane belt in the shape of three successive semi-ovals was rolled tightly around the connective tissue. The assembly was then re-inserted into the same rabbit to achieve further encapsulation. Finally, the autologous conduit-valveshaped construct with trileaflet valves was obtained by removing both the implanted rod and the polyurethane belt (Nakayama et al. 2009). A similar technology can also be used for creating vascular grafts or vascular stents covered with autologous tissue membranes (Huang et al. 2009). An important consideration is that full maturation of the newly formed tissue constructs and marked improvement of their mechanical properties can be achieved in a dynamic bioreactor (Huang et al. 2009).

\section{Future directions and questions to be resolved}

New materials for cardiovascular tissue engineering, decellularization techniques and dynamic bioreactors matching the condition in a healthy organism are being developed. The nanostructured materials mentioned above are promising, as they modulate both protein adsorption and cellular response in a more physiological manner. Some xenotransplants prepared by special advanced techniques are also promising, e.g. the usage of xenotransplants from $\alpha 1,3$-galactosyltransferase gene-knockout pig with prolonged survival (Ezzelarab et al. 2005). Novel heart valve replacements also contain DNA aptamers on their surface, which serve as capture molecules for circulating endothelial progenitor cells in the bloodstream. This approach would enable to skip the pre-endothelialization of the graft in vitro, which is often long-lasting and accompanied by a risk of infection
(Schleicher et al. 2009).

Advanced bioreactors are able to provide cells with a complex hemodynamic environment that can establish and maintain desirable cell phenotype (Butcher et al. 2008). However, it is still not clear what dynamic loading is appropriate to influence cell phenotype changes, stimulate and maintain cell differentiation and induce ECM remodeling without damage to the cellmaterial construct. Our experience with vascular and heart valve tissue engineering in pulse and perfusion bioreactors suggests that the initial loading of the cellmaterial constructs pre-formed under static cell culture conditions must be relatively low (i.e. much lower than those in arterial position in the living organism) in order to avoid damage to the cell and material. Then the loading should gradually be increased, according to the maturation capability of the tissue (Chlupáč et al. 2006, 2008, Straka et al. 2009). Similarly, in experiments carried out by other authors with cardiomyocytes, perfusion with culture medium below $1.5 \mathrm{ml} / \mathrm{min}$ supported the contractile properties of cardiomyocytes (Brown et al. 2008). However, excessive shear stress above $2.4 \mathrm{dyn} / \mathrm{cm}^{2}$ triggered $\mathrm{p} 38$ activation in neonatal cardiomyocytes and initiated their apoptosis (Dvir et al. 2007). Also in experiments in vivo, bioengineered prostheses are usually implanted into a pulmonary position, because the right side of the heart produces lower stress on the valve. In addition, any blood clots formed on the implant can be filtered in the lungs, and will not reach the general circulation (Korossis et al. 2000, Sutherland et al. 2005).

Concerning the implantation technique, there are requirements for the development of mini-invasive procedures, catheterization techniques, suitable stents, fine instruments for valve implantation, and advanced imaging systems, e.g. 3D echocardiography, computer tomography (CT). These procedures can in turn extend the spectrum of percutaneous interventions, which are currently reserved for patients having a high risk associated with surgical treatment.

Despite the indisputable progress that has been made in the construction of heart valve prostheses, many questions still remain to be fully answered, such as whether we can completely avoid xenogeneic and allogeneic materials. An attempt to avoid xenogeneic proteins, and simultaneously to preserve the biological properties of the material, involved the use of enzymatically cross-linked collagen-mimetic dendrimer with a triple-helical structure (Khew et al. 2008). Another 
promising possibility is the use of recombinant proteins and peptides, such as analogues of collagen, elastin or silk fibroin (Bini et al. 2006, Gelain et al. 2007, Kyle et al. 2009).

Further important questions are which cell types or co-cultures should be preferably used - whether differentiated, progenitor or stem cells, and whether the development of bioengineered heart valve can be tracked in respect of expression of genes involved in cell differentiation or calcification. As mentioned above, autologous differentiated cells are often available in small quantities, they proliferate relatively slowly and may have a limited life span, and therefore progenitor and stem cells are used. Among these cells, there is a tendency to avoid MSC in heart valve and vascular tissue engineering due to a high tendency to calcification of this cell type, which is derived from bone marrow. Alternative sources of progenitor cells are human umbilical cord cells (Hoerstrup et al. 2002), endothelial progenitor cells from peripheral blood (Zisch 2004), adipose-derived stem cells (Bunnell et al. 2008), skeletal muscle satellite cells (Danišovič et al. 2008) or amniotic fluid-derived cells (Schmidt et al. 2008).

Another issue is whether it is necessary to use valve-shaped grafts, or whether they can be tailored from a flat tissue sheet formed before implantation, which would be much simpler. If the second option is chosen, maturation of the construct in an appropriate dynamic bioreactor prior to implantation is highly recommended, due to the complicated architecture of the heart valve, as well as the high diversity and specialization of the heart cell types as mentioned above.

Other questions that need further intensive investigation are which scaffold properties (e.g. material, pore size or interfiber distance, stiffness, elasticity or degradation rate) are crucial for cell colonization and differentiation. As is known from bone tissue engineering, the appropriate pore size for bone tissue ingrowth inside the scaffolds ranges in hundreds of micrometers, optimally from $\sim 400$ to $600 \mu \mathrm{m}$. For fibrovascular tissue, this size has been reported to be much smaller, i.e. below $100 \mu \mathrm{m}$ (for a review, see Pamula et al. 2008, 2009). On the other hand, in decellularized bovine pericardium (ABP), a pore diameter of $\sim 25 \mu \mathrm{m}$, accompanied by about $60 \%$ pore interconnectivity and porosity, was unsuitable for cell ingrowth, and better results were obtained with synthetic scaffolds with values of $250 \mu \mathrm{m}$ and $90 \%$, respectively (Wei et al. 2005, Dong et al. 2009). In the latter study
(Dong et. al. 2009), the attractiveness of ABP for cell colonization was considerably improved by treating ABP with acetic acid, which increased the scaffold pore size and porosity.

\section{Conclusions}

Currently used mechanical and biological heart valve prostheses have serious disadvantages. Therefore, efforts are being made to prepare bioartificial heart valves with an autologous biological component using tissue engineering methods. However, approaches for the development of the tissue-engineered heart valves still have several limitations and there are unresolved questions. Promising approaches seem to be the use of modified decellularized xenogenic or allogenic scaffolds (particularly those modified by RDG-containing polypeptides) or the use of xenotransplants from $\alpha 1,3-$ galactosyltransferase gene-knockout pig with prolonged survival. The development of materials containing polymerized extracellular matrix and entrapped cells enables an analysis of molecular mechanisms of cell-toextracellular matrix interactions, cell reaction to mechanical stimulation, as well as cell-cell interaction in co-cultures of different cells types. Some advanced technologies hold out high hopes, e.g. rapid prototyping and nanospider technology for creating a nanoarchitecture to promote the colonization of scaffolds with cells. Analyses of the adhesion, proliferation, migration and differentiation potential of several cell types, including stem and progenitor cells, in cultures on degradable synthetic scaffolds with different chemical compositions, porosity or elasticity and under various dynamic conditioning, are also important tasks for further research in this area. In terms of implantation techniques, further development of appropriate tools can be anticipated, as well as stents for percutaneous valve implantation.

\section{Conflict of Interest}

There is no conflict of interest.

\section{Acknowledgements}

This study was supported by the Centre for Cardiovascular Research (grant No. 1M6798582302 provided by the Ministry of Education, Youth and Sports of the Czech Republic) and by the Academy of Sciences of the Czech Republic (grant No. 1QS500110564). Mr. Robin Healey (Czech Technical University, Prague) 
is gratefully acknowledged for his language revision of the manuscript. We also thank Mrs. Jana Voborníková for her excellent technical assistance in preparing the manuscript.

\section{References}

AIKAWA EP, WHITTAKER P, FARBER M, MENDELSON K, PADERA R, SCHOEN F: Human semilunar cardiac valve remodeling by activated cells from fetus to adult: Implications for postnatal adaptation, valve pathology and tissue engineering. Circulation 113: 1344-1352, 2006.

ASCHERMANN M: Kardiologie. (in Czech) Galen, Prague, 2004, p. 1322.

BAGUNEID MS, SEIFALIAN AM, SALACINSKI HJ, MURRAY D, HAMILTON G, WALKER MG: Tissue engineering of blood vessels. Br J Surg 93: 282-290, 2006.

BENSE CA, WOODHOUSE KA: Plasmin degradation of fibrin coatings on synthetic polymer substrates. $J$ Biomed Mater Res 46: 305-314, 1999.

BINI E, FOO CW, HUANG J, KARAGEORGIOU V, KITCHEL B, KAPLAN DL: RGD-functionalized bioengineered spider dragline silk biomaterial. Biomacromolecules 7: 3139-3145, 2006.

BJÖRK VO: The history of the Björk-Shiley tilting disc valve. Med Instrum 11: 80-81, 1977.

BOENHOEFFER P, BOUDJEMLINE Y, SALIBA Z, MECKX J, AGGOUN Y, BONNET D, ACAR P, LE BIDOIS J, SIDI D, KANACHER J: Percutaneous replacement of pulmonary valve in a right-ventricle to pulmonaryartery prosthetic conduit with valve dysfunction. Lancet 356: 1403-1405, 2000.

BOOTH C, KOROSSIS SA, WILCOX HE, WATTERSON KG, KEARNEY JN, FISHER J, INGHAM E: Tissue engineering of cardiac valve prostheses. I. Development and histological characterization of an acellular porcine scaffold. J Heart Valve Dis 11: 457-462, 2002.

BROWN MA, IYER RK, RADISIC M: Pulsatile perfusion bioreactor for cardiac tissue engineering. Biotechnol Prog 24: 907-920, 2008.

BUNNELL BA, FLAAT M, GAGLIARDI C, PATEL B, RIPOLL C: Adipose-derived stem cells: isolation, expansion and differentiation. Methods 45: 115-120, 2008.

BUTCHER JT, PENROD AM, GARCIA AJ, NEREM RM: Unique morphology and focal adhesion development of valvular endothelial cells in static and fluid flow environments. Arterioscler Thromb Vasc Biol 24: 1429-1434, 2004.

BUTCHER JT, TRESSEL S, JOHNSON T, TURNER D, SORESCU G, JO H, NEREM RM: Transcriptional profiles of valvular and vascular endothelial cells reveal phenotypic differences: Influence of shear stress. Arterioscler Thromb Vasc Biol 26: 69-77, 2005.

BUTCHER JT, SIMMONS CA, WARNOCK JN: Mechanobiology of the aortic heart valve. J Heart Valve Dis 17: 6273, 2008.

CHESTER AH, MISFELD M, YACOUB MH: Receptor-mediated contraction of aortic valve leaflets. $J$ Heart Valve Dis 9: 250-255, 2000.

CHLUPÁČ J, FILOVÁ E, RIEDEL T, BRYNDA E, REMY-ZOLGHADRI M, BAREILLE R, FERNANDEZ P, DACULSI R, BORDENAVE L, BAČÁKOVÁ L: Human endothelium on vascular prostheses modified by extracellular matrix proteins in a flow experiment. Eng Biomater 58-60: 10-13, 2006.

CHLUPÁČ J, FILOVÁ E, RIEDEL T, BRYNDA E, PAMULA E, REMY-ZOLGHADRI M, BAREILLE R, FERNANDEZ P, DACULSI R, BURGET C, BORDENAVE L, BAČÁKOVÁ L: Endothelial cells seeded on protein multilayer assemblies under shear stress. Physiol Res 57: 77P, 2008.

CIMINI M, ROGERS KA, BOUGHNER DR: Smoothelin-positive cells in human and porcine semilunar valves. Histochem Cell Biol 120: 307-317, 2003.

CLARK RAF: Fibrin and wound healing. Ann NY Acad Sci 936: 355-367, 2001.

CONCHA M, ARANDA PJ, CASARES J, MERINO C, ALADOS P, MUNOZ I, GONZALES JR, RIBES R, VILLALBA R: The Ross procedure. J Card Surg 19: 401-409, 2004. 
CRIBIER A, ELTCHANINOFF H, BASH A, BORENSTEIN N, TRON C, BAUER F, DERUMEAUX G, ANSELME F, LABORDE F, LEON MB: Percutaneous transcatheter implantation of an aortic valve prosthesis for calcific aortic stenosis: first human case description. Circulation 106: 3006-3008, 2002.

CUMMINGS CL, GAWLITTA D, NEREM RM, STEGEMANN JP: Properties of engineered vascular constructs made from collagen, fibrin, and collagen-fibrin mixtures. Biomaterials 25: 3699-3706, 2004.

DAAMEN WF, VEERKAMP JH, VAN HEST JCM, VAN KUPPEVELT TH: Elastin as a biomaterial for tissue engineering. Biomaterials 28: 4378-4398, 2007.

DANIŠOVIČ L, VARGA I, POLÁK S, ULIČNÁ M, BOHMER D, VOJTASSAK J: Morphology of in vitro expanded human muscle-derived stem cells. Biomed Pap Med Fac Univ Palacky Olomouc Czech Repub 152: 235-238, 2008.

DECK JD: Endothelial cell orientation on aortic valve leaflets. Cardiovasc Res 20: 760-767, 1986.

DONG X, WEI X, YI W, GU C, KANG X, LIU Y, LI Q, YI D: RGD-modified acellular bovine pericardium as a bioprosthetic scaffold for tissue engineering. J Mater Sci Mater Med 2009, Jun 9 [Epub ahead of print].

DVIR T, LEVY O, SHACHAR M, GRANOT Y, COHEN S: Activation of the ERK1/2 cascade via pulsatile interstitial fluid flow promotes cardiac tissue assembly. Tissue Eng 13: 2185-2193, 2007.

EISENBERG LM, MARKWALD RR: Molecular regulation of atrioventricular valvuloseptal morphogenesis. Circ Res 77: 1-6, 1995.

EMERY RW, NICOLOFF DM: St. Jude Medical cardiac valve prosthesis: in vitro studies. $J$ Thorac Cardiovasc Surg 78: 269-276, 1979.

EMERY RW, METTLER E, NICOLOFF DM: A new cardiac prosthesis: the St. Jude Medical cardiac valve: in vivo results. Circulation 60: 48-54, 1979.

ENGELMAYR GC Jr, SACKS MS: Prediction of extracellular matrix stiffness in engineered heart valve tissues based on nonwoven scaffolds. Biomechan Model Mechanobiol 7: 309-321, 2008.

ENGELMAYR GC Jr, SALES VL, MAYER JE Jr, SACKS MS: Cyclic flexure and laminar flow synergistically accelerate mesenchymal stem cell-mediated engineered tissue formation: Implications for engineered valve tissues. Biomaterials 27: 6083-6095, 2006.

EZZELARAB M, YAMADA K; COOPER DKC; SACHS DH: Pig-to-nonhuman primate organ xenotransplantation. Curr Opin Organ Transplant 10: 234-239, 2005.

FARALLI JA, SCHWINN MK, GONZALES JM Jr, FILLA MS, PETERS DM: Functional properties of fibronectin in the trabecular meshwork. Exp Eye Res 88: 689-693, 2009.

FAYET C, BENDECK MP, GOTLIEB AI: Cardiac valve interstitial cells secrete fibronectin and form fibrillar adhesions in response to injury. Cardiovasc Pathol 16: 203-211, 2007.

FILOVÁ E, BRYNDA E, RIEDEL T, BAČÁKOVÁ L, CHLUPÁČ J, LISÁ V, HOUSKA M, DYR JE: Vascular endothelial cells on two- and three-dimensional fibrin assemblies for biomaterial coatings. J Biomed Mater Res $A$ 90: 55-69, 2009a.

FILOVÁ E, STRAKA F, BAČÁKOVÁ L, MUNZAROVÁ M, SVOBODOVÁ J: Growth of valve interstitial cells on aligned and randomly oriented electrospun nanofibres. Joint meeting of the Society for Heart Valve Disease \& Heart Valve Society of America, Berlin, p. 379, 2009b.

FLANAGAN TC, WILKINS B, BLACK A, JOCKENHOEVEL S, SMITH TJ, PANDIT AS: A collagenglycosaminoglycan co-culture model for heart valve tissue engineering applications. Biomaterials 27: 22332246, 2006.

FLANAGAN TC, CORNELISSEN C, KOCH S, TSCHOEKE B, SACHWEH S, SCHMITZ-RODE T, JOCKENHOEVEL S: The in vitro development of autologous fibrin-based tissue-engineered valves through optimised dynamic conditioning. Biomaterials 28: 3388-3397, 2007.

FORBESS JM, SHAH AS, ST LOUIS JD, JAGGERS JJ, UNGERLEIDER RM: Cryopreserved homografts in the pulmonary position: determinants of durability. Ann Thorac Surg 71: 54-60, 2001.

GELAIN F, HORII A, ZHANG S: Designer self-assembling peptide scaffolds for 3-D tissue cell cultures and regenerative medicine. Macromol Biosci 7: 544-551, 2007.

GOJO S, GOJO N, TAKEDA Y, MORI T, ABE H, KYO S, HATA J, UMEZAWA A: In vivo cardiovasculogenesis by direct injection of isolated adult mesenchymal stem cells. Exp Cell Res 288: 51-59, 2003. 
GRASSL ED, OEGEMA TR, TRANQUILLO RT: Fibrin as an alternative biopolymer to type-I collagen for the fabrication of a media equivalent. J Biomed Mater Res 60: 607-612, 2002.

GRASSL ED, OEGEMA TR, TRANQUILLO RT: A fibrin-based arterial media equivalent. J Biomed Mater Res A 66: 550-561, 2003.

HOCKING DC, KOWALSKI K: A cryptic fragment from fibronectin's III1 module localizes to lipid rafts and stimulates cell growth and contractility. J Cell Biol 158: 175-184, 2002.

HOERSTRUP SP, KADNER A, BREYMANN C, MAURU CF, GUENTER CI, SODIAN R, VISJAGER JF, ZUND G, TURINA MI: Living, autologous pulmonary artery conduits tissue engineered from human umbilical cord cells. Ann Thorac Surg 74: 46-52, 2002.

HORBETT TA: Principles underlying the role of adsorbed plasma proteins in blood interactions with foreign materials. Cardiovasc Pathol 2: 137S-148S, 1993.

HUANG H, ZHOU YM, ISHIBASHI-UEDA H, TAKAMIZAWA K, ANDO J, KANDA K, YAKU H, NAKAYAMA Y: In vitro maturation of "biotube" vascular grafts induced by a 2-day pulsatile flow loading. J Biomed Mater Res B Appl Biomater 91: 320-328, 2009.

HUFNAGEL CA, VILLEGAS PD, NAHAS H: Experiences with new types of aortic valvular prostheses. Ann Surg 147: 636-644, 1958.

IOP L, RENIER V, NASO F, PICCOLI M, BONETTI A, GANDAGLIA A, POZZOBON M, PAOLIN A, ORTOLANI F, MARCHINI M, SPINA M, DE COPPI P, SARTORE S, GEROSA G: The influence of heart valve leaflet matrix characteristics on the interaction between human mesenchymal stem cells and decellularized scaffolds. Biomaterials 30: 4104-4116, 2009.

ITO S, ISHIMARU S, WILSON SE: Inhibitory effect of type I collagen gel containing $\alpha$-elastin on proliferation and migration of vascular smooth muscle and endothelial cells. Cardiovasc Surg 5: 176-183, 1997.

JACKSON MR: Fibrin sealant in surgical practice: an overview. Am J Surg 182: 1-7, 2001.

JOCKENHOEVEL S, ZUND G, HOERSTRUP SP, CHALABI K, SACHWEH JS, DEMIRCAN L, MESSMER BJ, TURIN A: Fibrin gel - advantages of a new scaffold in cardiovascular tissue engineering. Eur $J$ CardioThorac Surg 19: 424-430, 2001.

KARNIK SK, BROOKE BS, BAYES-GENIS A, SORENSEN L, WYTHE JD, SCHWARTZ RS, KEATING MT, LI DY: A critical role of elastin signaling in vascular morphogenesis and disease. Development 130: 411-423, 2003.

KHEW ST, YANG QJ, TONG YW: Enzymatically crosslinked collagen-mimetic dendrimers that promote integrintargeted cell adhesion. Biomaterials 29: 3034-3045, 2008.

KILNER PJ, YANG GZ, WILKES AJ, MOHIADDIN RH, FIRMIN DN, YACOUB MH: Asymmetric redirection of flow through the heart. Nature 404: 759-761, 2000.

KNIGHT RL WILCOX HE, KOROSSIS SA, FISHER J, INGHAM E: The use of acellular matrices for the tissue engineering of cardiac valves. Proc Inst Mech Eng H 222: 129-143, 2008.

KOENIG AL, GAMBILLARA V, GRAINGER DW: Correlating fibronectin adsorption with endothelial cell adhesion and signaling on polymer substrates. J Biomed Mater Res A 64: 20-37, 2003.

KOROSSIS SA, FISHER J, INGHAM E: Cardiac valve replacement: A bioengineering approach. Biomed Mater Eng 10: 83-124, 2000.

KRAMMER A, CRAIG D, THOMAS WE, SCHULTEN K, VOGEL V: A structural model for force regulated integrin binding to fibronectin's RGD-synergy site. Matrix Biol 21: 139-147, 2002.

KU CH, JOHNSON PH, BATTEN P, SARATHCHANDRA P. CHAMBRES RC, TAYLOR PM, YACOUB MH, CHESTER AH: Collagen synthesis by mesenchymal stem cells and aortic valve interstitial cells in response to mechanical stretch. Cardiovasc Res 71: 548-556, 2006.

KYLE S, AGGELI A, INGHAM E, MCPHERSON MJ: Production of self-assembling biomaterials for tissue engineering. Trends Biotechnol 27: 423-433, 2009.

LEE CH, SINGLA A, LEE Y: Biomedical applications of collagen. Int J Pharm 221: 1-22, 2001.

LAI PH, CHANG Y, CHEN SC, WANG CC, LIANG HC, CHANG WC, SUNG HW: Acellular biological tissues containing inherent glycosaminoglycans for loading basic fibroblast growth factor promote angiogenesis and tissue regeneration. Tissue Eng. 12: 2499-2508, 2006. 
LI YS, HAGA JH, CHIEN S: Molecular basis of the effect of shear stress on vascular endothelial cells. $J$ Biomech 38 : 1949-1971, 2005.

LICHTENBERG A, TUDORACHE I, CEBOTARI S, SUPRUNOV M, TUDORACHE G, GOERLER H, PARK JK, HILFIKER-KLEINER D, RINGES-LICHTENBERG S, KARCK M, BRANDES G, HILFIKER A, HAVERICH A: Preclinical testing of tissue-engineered heart valves re-endothelialized under simulated physiological conditions. Circulation 114 (1 Suppl): I-559-I-565, 2006.

LIU SQ, TIECHE C, ALKEMA PK: Neointimal formation on vascular lamina and collagen matrix scaffolds implanted in the rat aortae. Biomaterials 25: 1869-1882, 2004.

LIU Y, YANAI R, LU Y, KIMURA K, NISHIDA T: Promotion by fibronectin of collagen gel contraction mediated by human corneal fibroblasts. Exp Eye Res 83: 1196-1204, 2006.

LO D, VESELY I: Biaxial strain analysis of the porcine aortic valve. Ann Thorac Surg 60: S374-S378, 1995.

MARION NW, MAO JJ: Mesenchymal stem cells and tissue engineering. Methods Enzymol 420: 339-361, 2006.

MASTERS KS, SHAH DN, LEINWAND LA, ANSETH KS: Crosslinked hyaluronan scaffolds as a biologically active carrier for valvular interstitial cells. Biomaterials 26: 2517-2525, 2005.

MENDELSON K, SCHOEN FJ: Heart valve tissue engineering: concepts, approaches, progress, and challenges. Ann Biomed Eng 34: 1799-1819, 2006.

MERRYMAN WD, YOUN I, LUKOFF HD, KRUEGER PM, GUILAK F, HOPKINS RA, SACKS MS: Correlation between heart valve interstitial cell stiffness and transvalvular pressure: implications for collagen biosynthesis. Am J Physiol 290: H224-H231, 2006.

MIDWOOD KS, WILLIAMS LV, SCHWARZBAUER JE: Tissue repair and the dynamics of the extracellular matrix. Int J Biochem Cell Biol 36: 1031-1037, 2004.

MOL A, DRIESSEN NJB, RUTTEN MC, HOERSTRUP SP, BOUTEN CVC, BAAIJENS PT: Tissue engineering of human heart valve leaflets: A novel bioreactor for a strain-based conditioning approach. Ann Biomed Eng 33: 1778-1788, 2005.

NAKAYAMA Y, YAMANAMI M, YAHATA Y, TAJIKAWA T, OHBA K, WATANABE T, KANDA K, YAKU H: Preparation of a completely autologous trileaflet valve-shaped construct by in-body tissue architecture technology. J Biomed Mater Res B Appl Biomater 91: 813-818, 2009.

PAMULA E, BAČÁKOVÁ L, FILOVÁ E, BUCZYNSKA J, DOBRZYNSKI P, NOSKOVÁ L, GRAUSOVÁ L: The influence of pore size on colonization of poly(L-lactide-glycolide) scaffolds with human osteoblast-like MG 63 cells in vitro. J Mater Sci Mater Med 19: 425-435, 2008.

PAMULA E, FILOVÁ E, BAČÁKOVÁ L, LISÁ V, ADAMCZYK D: Resorbable polymeric scaffolds for bone tissue engineering: The influence of their microstructure on the growth of human osteoblast-like MG 63 cells. J Biomed Mater Res A, 89A: 432-443, 2009.

POPELOVÁ J, BENEŠOVÁ M, BRTKO M, ČERNÝ Š, KRUPIČKA J, ČERBÁK R, DOMINIK J, MAREK T: Recommended procedures for the diagnostics and therapy of heart valve defects in adults. Cor Vasa 49 (Suppl): 6-45, 2007.

PŘÁDNÝ M, MICHÁLEK J, LESNÝ P, HEJČL A, VACÍK J: Macroporous hydrogels based on 2-hydroxyethyl methacrylate. Part 5. Hydrolytically degradable materials. J Mater Sci Mater Med 17: 1357-1364, 2006.

RAMAMURTHI A, VESELY I. Evaluation of matrix-synthesis potential of crosslinked hyaluronan gels for tissue engineering of aortic heart valves: Biomaterials 26: 999-1010, 2005.

RIEDEL T, BRYNDA E, DYR JE, HOUSKA M: Controlled preparation of thin fibrin films immobilized at solid surfaces. J Biomed Mater Res A 88: 437-447, 2009.

RUEL J, LACHANCE G: A new bioreactor for the development of tissue-engineered heart valves. Ann Biomed Eng 37: 674-681, 2009.

SCHLEICHER M, WENDEL HP, FRITZE O, STOCK U: In vivo tissue engineering of heart valves: evolution of a novel concept. Regen Med 4: 613-619, 2009.

SCHMIDT D, ACHERMANN J, ODERMATT B, GENONI M, ZUND G, HOERSTRUP SP: Cryopreserved amniotic fluid-derived cells: a lifelong autologous fetal stem cell source for heart valve tissue engineering. J Heart Valve Dis 17: 446-455, 2008. 
SCHOEN FJ: Evolving concepts of cardiac valve dynamics. The continuum of development, functional structure pathobiology and tissue engineering. Circulation 118: 1864-1880, 2008.

SCHURCH WT, SEEMAYER TA, GABBIANI G: The myofibroblast: a quarter century after its discovery. Am J Surg Pathol 22: 141-147, 1998.

SCOTT M, VESELY I: Morphology of porcine aortic valve cusp elastin. J Heart Valve Dis 5: 464-471, 1996.

SEEBURGER J, GROESDONK H, BORGER MA, MERK D, ENDER J, FALK V, MOHR FW, DOLL N: Quadruple valve replacement for acute endocarditis. $J$ Thorac Cardiovasc Surg 137: 1564-1565, 2009.

SEEGER JM, KLINGMAN N: Improved in vivo endothelialization of prosthetic grafts by surface modification with fibronectin. J Vasc Surg 8: 476-482, 1988.

SENTHILNATHAN V, TREASURE T, GRUNKEMEIER G, STARR A: Heart valves: which is the best choice? Cardiovasc Surg 7: 393-397, 1999.

SHIH YRV, CHEN CN, TSAI SW, WANG YJ, LEE OK: Growth of mesenchymal stem cells on electrospun type I collagen nanofibers. Stem Cells 24: 2391-2397, 2006.

SIMON P, KASIMIR MT, SEEBACHER G, WEIGEL G, ULLRICH R, SALZER-MUHAR U, RIEDER E, WOLNER E: Early failure of the tissue engineered porcine heart valve SYNERGRAFT in pediatric patients. Eur $J$ Cardiothorac Surg. 23: 1002-1006, 2003.

SIMMONS CA, GRANT GR, MANDUCHI E, DAVIES PF: Spatial heterogeneity of endothelial phenotypes correlates with side-specific vulnerability to calcification in normal porcine aortic valves. Circ Res 96: 792-799, 2005.

SODIAN R, HOERSTRUP SP, SPERLING JS, DAEBRITZ S, MARTIN DP, MORAN AM, KIM BS, SCHOEN F, VACANTI JP, MAYER JE: Early in vivo experience with tissue-engineered trileaflet heart valves. Circulation 102 (Suppl III): III-22-III-29, 2000.

STARR A: The Starr-Edwards valve. J Am Coll Cardiol 6: 899-903, 1985.

STRAKA F, FILOVÁ E, CHLUPÁČ J, BAČÁKOVÁ L, PIRK J: Bilayer of vascular smooth muscle cells (SMC) and endothelial cells (EC) on a nanofibre mesh in a pulse Bioreactor. Joint meeting of the Society for Heart Valve Disease \& Heart Valve Society of America, Berlin, 2009, p. 380.

SUTHERLAND FWH, PERRY TE, YU Y, SHERWOOD MC, RABKIN E, MASUDA Y, GARCIA GA, MCLELLAN DL, ENGELMAYR GC Jr, SACKS MS, SCHOEN FJ, MAYER JE Jr: From stem cells to viable autologous semilunar heart valve. Circulation 111: 2783-2791, 2005.

SYEDAIN ZH, WEINBERG JS, TRANQUILLO RT: Cyclic distension of fibrin-based tissue constructs: Evidence of adaptation during growth of engineered connective tissue. Proc Natl Acad Sci USA 105: 6537-6542, 2008.

TAYLOR PM, BATTEN P, BRAND NJ, THOMAS PS, YACOUB MH: The cardiac valve interstitial cells. Int $J$ Biochem Cell Biol 35: 113-118, 2003.

TAYLOR PM, SACHLOS E, DREGER SA, CHESTER AH, CZERNUSZKA JT, YACOUB MH: Interaction of human valve interstitial cells with collagen matrix manufactured using rapid prototyping. Biomaterials 27: 2733-2737, 2006.

TEDDER ME, LIAO J, WEED B, STABLER C, ZHANG H, SIMIONESCU A, SIMIONESCU DT: Stabilized collagen scaffolds for heart valve tissue engineering. Tissue Eng Part A 15: 1257-1268, 2009.

TULLA M, PENTIKAINEN OT, VIITASALO T, KAPYLA J, IMPOLA U, NYKVIST P, NISSNEN L, JOHNSON MS, HEINO J: Selective binding of collagen subtypes by integrin alpha 1I, alpha 2I, and alpha 10I domains. J Biol Chem 276: 48206-48212, 2001.

VESELY I: Heart valve tissue engineering. Circ Res 97: 743-755, 2005.

VESELY I, BOUGHNER D: Analysis of the bending behaviour of porcine xenograft leaflet and of neutral aortic valve material: bending stiffness, neutral axis and shear measurements. J Biomech 22: 655-671, 1989.

WALPOTH BH, ZAMMARETTI P, CIKIRIKCIOGLU M, KHABIRI E, DJEBAILI MK, PACHE JC, TILLE JC, AGGOUN Y, MOREL D, KALANGOS A, HUBBELL JA, ZISCH AH: Enhanced intimal thickening of expanded polytetrafluoroethylene grafts coated with fibrin or fibrin-releasing vascular endothelial growth factor in the pig carotid artery interposition model. J Thorac Cardiovasc Surg 133: 1163-1170, 2007.

WEI HJ, LIANG HC, LEE MH, HUANG YC, CHANG Y, SUNG HW: Construction of varying porous structures in acellular bovine pericardia as a tissue-engineering extracellular matrix. Biomaterials 26: 1905-1913, 2005.

WEIND KL, ELLIS CG, BOUGHNER DR: The aortic valve blood supply. $J$ Heart Valve Dis 9: 1-7, 2000. 
WESTON MW, LABORDE DV, YOGANATHEN AP: Estimation of the shear stress on the surface of an aortic valve leaflet. Ann Biomed Eng 27: 572-579, 1999.

WHITE JK, AGNIHOTRI AK, TITUS JS, TORCHIANA DT: A stentless trileaflet valve from a sheet of decellularized porcine small intestinal submucosa. Ann Thorac Surg 80: 704-707, 2005.

WILLIAMS C, LIAO J, JOYCE EM, WANG B, LEACH JB, SACKS MS, WONG JY: Altered structural and mechanical properties in decellularized rabbit carotid arteries. Acta Biomater 5: 993-1005, 2009.

WITTMER CR, PHELPS JA, SALTZMAN WM, VAN TASSEL PR: Fibronectin terminated multilayer films: protein adsorption and cell attachment studies. Biomaterials 28: 851-860, 2007.

YACOUB MH, TAKKENBERG JJ: Will heart valve tissue engineering change the world? Nat Clin Pract Cardiovasc Med 2: 60-61, 2005.

YANG X, SHAH JD, WANG H: Nanofiber enabled layer-by-layer approach toward three-dimensional tissue formation. Tissue Eng Part A 15: 945-956, 2009.

YAP CH, YII M: Allograft aortic valve replacement in the adult: a review. Heart Lung Circ 13: 41-51, 2004.

YE Q, ZÜND G, BENEDIKT P, JOCKENHOEVEL S, HOERSTRUP SP, SAKYAMA S, HUBBELL JA, TURINA M: Fibrin gel as a three dimensional matrix in cardiovascular tissue engineering. Eur J Cardiothorac Surg 17: 587-591, 2000.

YILDIZ A, OZCAN F, DOGAN M, OZLÜ MF, SASMAZ A: Twenty-two years without anticoagulation with metallic heart valve. J Natl Med Assoc 98: 1348-1349, 2006.

ZHOU LL, MARUYAMA I, LI YH, CHENG EL, YUE B: Expression of integrin receptors in the human trabecular meshwork. Curr Eye Res 19: 395-402, 1999.

ZILLA P, BRINK J, HUMAN P, BEZUIDENHOUT D: Prosthetic heart valves: catering for the few. Biomaterials 29: 385-406, 2008.

ZISCH AH: Tissue engineering of angiogenesis with autologous endothelial progenitor cells. Curr Opin Biotechnol 15: 424-429, 2004. 